\title{
New approach to materials behaviour studies in high-speed flue gas from oxy-steam combustion
}

\author{
M.C. Mayoral, J.M. Andrés, C. Dueso, B. Rubio \\ Instituto de Carboquímica-CSIC, Miguel Luesma 4, 50018 Zaragoza, Spain
}

\begin{abstract}
Some new proposals are being considered aiming at improving the efficiency and operability of oxy-combustion power plants, such as the so-called oxy-steam combustion. This process consists in replacing the carbon dioxide by steam in the firing atmosphere. One of the main uncertainties for the feasibility of the oxy-steam technology is the materials resistance to steam corrosion at high temperature, mainly due to chromium vaporization. The novel approach to the issue presented in this work is the generation of realistic flue gas velocity $\left(20 \mathrm{~m} \cdot \mathrm{s}^{-1}\right)$ in flames produced with a thermal spray gun using $\mathrm{H}_{2}$ as fuel. Gas composition was selected to match expected final $\mathrm{H}_{2} \mathrm{O}$ content after combustion: 40 and $60 \% \mathrm{H}_{2} \mathrm{O}$ in $\mathrm{CO}_{2}$ with excess of $\mathrm{O}_{2}$. A set of metallic steels and alloys (SS304, SS310, I800HT, Kanthal and IN617) was preoxidised in air to generate external oxide scales. After preoxidation, the samples were treated under steam flames at $700{ }^{\circ} \mathrm{C}$, placed in a position either parallel or perpendicular to the flame axis. Surface oxides composition was compared to that obtained in a quasi-static furnace, where metallic samples were exposed to steam atmosphere at $700{ }^{\circ} \mathrm{C}$ for 20 hours $(50 \%$ steam, $45 \% \mathrm{CO}_{2}$ and $5 \% \mathrm{O}_{2}$ ). The characterisation of the surfaces was performed using low-angle XRD and SEM-EDX for a precise measuring of the variation of oxide amount and chromium content. The analyses showed that mixed $\mathrm{Cr}-\mathrm{Mn}$ and $\mathrm{Cr}-\mathrm{Fe}$ external oxides formed during the preoxidation stage suffered the depletion of the surface chromium when they were exposed parallel to the steam flame axis, as a simulation of the lateral flue gas pass in the heat-exchanger tubing. $\mathrm{Cr}$ depletion was also observed in the windside of tubes (perpendicular to flame axis) but in minor extent. The reduction in the $\mathrm{Cr}$ amount of the samples when tested in the vapour furnace was negligible compared to the $\mathrm{Cr}$ loss found after treatment under high velocity flames. The presence of external $(\mathrm{Mn}, \mathrm{Cr})_{3} \mathrm{O}_{4}$ in preoxidised SS310 and SS304 did not provide an effective protection against $\mathrm{Cr}$ volatilization in the steam flame treatment, whereas surface alumina in Kanthal seemed to prevent Cr volatilization.
\end{abstract}


Keywords: Oxy-steam combustion, Cr vaporization, steam corrosion 


\section{Introduction}

Oxy-fuel combustion technology for power generation from fossil fuels with $\mathrm{CO}_{2}$ capture has reached the demonstration stage $[1,2]$, Great experience has been achieved worldwide at different unit sizes, both in pulverized fuel and fluidized bed reactors [3, 4]. An increase in system efficiency is foreseen with the reduction and even suppression of the recycled $\mathrm{CO}_{2}$ [5] in the so-called "third generation" oxy-combustion processes. Among several proposed layouts, oxy-steam combustion, also called "hydroxyfuel" combustion, postulates the use of water vapour instead of recycled gases as temperature moderator [6-8]. With this configuration, final $\mathrm{CO}_{2}$ purity in the flue gas after the condensation of steam would be higher than in dry oxy-fuel combustion. Simplicity is one of the main advantages of this process when compared to oxy-fuel combustion since the recycled flue gas stream is minimised or avoided. Numerical studies concluded that the energy savings with the avoidance of gas recycling, separation and compression could be close to compensate the decrease in thermal efficiency due to the use of steam as flame moderator [9]. From the system efficiency perspective, oxy-steam combustion may offer other macroscopic advantages: start-up and shut-down are easier, auxiliary equipment is downsized and $\mathrm{NO}_{\mathrm{x}}$ formation is reduced. Research about this process has been mainly focused on coal ignition, heat transfer efficiency, effect of the $\mathrm{O}_{2}$ ratio, kinetics in $\mathrm{H}_{2} \mathrm{O}$-rich environments, system performance, economic feasibility and technical integration [9-14].

One of the uncertainties of the oxy-steam technology is the performance of the metallic surfaces of heat-exchangers under high steam partial pressure, since the physical and chemical properties of steam are very different from those of $\mathrm{CO}_{2}$ and $\mathrm{N}_{2}$. Other emerging oxy-fuel technologies, such as direct contact steam generation [15], oxy-fuel Brayton combustors [16] and direct steam generation with high-pressure heat recovery [17], are related to the use of high-temperature steam- $\mathrm{CO}_{2}$ flows, so materials performance under this atmosphere is of major interest. Over last years, considerable effort has been directed to elucidate the impact of water vapour on the oxidation behaviour of metallic materials at high temperature [18-21]. The oxidation behaviour of a number of ferritic and austenic steels and $\mathrm{Ni}-\mathrm{Cr}$ based alloys has been studied in the gas atmosphere present in oxy-fuel combustion with steam concentrations of 25 and $30 \%$ at $650{ }^{\circ} \mathrm{C}$ and $700{ }^{\circ} \mathrm{C}$ [22-24] and disruptive oxidation and carburization incidence have been described. Moreover, it has been found that materials containing 18-20\% Cr, 
with the ability to form $\mathrm{Cr}_{2} \mathrm{O}_{3}$-rich protective scales in harsh combustion environments, when exposed to $40 \%$ steam in $\mathrm{O}_{2}$ conditions, may undergo catastrophic corrosion between $600{ }^{\circ} \mathrm{C}$ and $800{ }^{\circ} \mathrm{C}[25,26]$. This degradation mechanism has been assigned to chromia evaporation $[27,28]$, according to the following reaction:

$\mathrm{Cr}_{2} \mathrm{O}_{3}(\mathrm{~s})+2 \mathrm{H}_{2} \mathrm{O}(\mathrm{g})+1.5 \mathrm{O}_{2}(\mathrm{~g}) \rightarrow 2 \mathrm{CrO}_{2}(\mathrm{OH})_{2}(\mathrm{~g})$

The evaporation rate of $\mathrm{CrO}_{2}(\mathrm{OH})_{2}$ grows with increasing partial pressures of water vapour, oxygen concentration, temperature, gas velocity and chromia activity [22, 29]. The rate of evaporation is surface controlled, because volatile $\mathrm{CrO}_{2}(\mathrm{OH})_{2}$ diffuses from the surface through the stagnant interphase and is carried away by the gas flow. As gas velocity increases, the diffusion layer becomes thinner, resulting in an augmentation of the evaporation rate [30]. The volatilisation of surface chromia involves chromium losses in scale and the subsequent $\mathrm{Cr}$ depletion in subscale substrate that migrates to generate new oxide scale, rendering the breakdown of protective scales when oxygen or air are present above $700{ }^{\circ} \mathrm{C}[28]$.

The effect of water vapour on $\mathrm{Cr}$ vaporization has been studied in solid oxide fuel-cell interconnects, where the gas velocity is not a determining parameter [31-33]. These tests carried out at lab-scale, where linear velocity of simulated flue gas is in the range of 0.02 to $0.06 \mathrm{~m} / \mathrm{s}$, are not resembling turbulent regime in the convective zone inside commercial burners [28]. Recent contributions about the oxidation behaviour and $\mathrm{Cr}$ loss in wet air of alloy 625 have demonstrated that high gas flow rates $\left(6 \mathrm{~m} \cdot \mathrm{s}^{-1}\right.$ linear flow velocity) significantly influenced the limited oxidation life of metallic surfaces [34]. Flue gas velocity in the convective section of combustion burners is considered to be $20 \mathrm{~m} \cdot \mathrm{s}^{-1}[35,36]$ and only a few works about $\mathrm{Cr}$ evaporation at realistic gas velocities can be found in literature. Tylczak et al. [37] investigated Cr volatilization at $760{ }^{\circ} \mathrm{C}$ under $57 \% \mathrm{H}_{2} \mathrm{O}$ using a whirling arm apparatus designed for high speed erosion/corrosion testing of Ni alloys in hostile gas environments, reaching $26.5 \mathrm{~m} \cdot \mathrm{s}^{-1}$. They observed that the extent of $\mathrm{Cr}$ depletion in the metallic surface varied with the alloying elements. Alloying elements, such as Ti and Mn, may play a role in reducing the formation of volatile $\mathrm{Cr}$ oxyhydroxide by means of the creation of outer layers of $\mathrm{TiO}_{2}$ and $\mathrm{Cr}-\mathrm{Mn}$ spinels [38]. The effect of $\mathrm{Mn}$ concentration on the reduction of $\mathrm{Cr}$ evaporation has been deeply studied in the range of $600^{\circ} \mathrm{C}$ to $850^{\circ} \mathrm{C}$ in solid oxide fuel cells exposure conditions, which are actually low gas velocity [31, 33, 39]. 
The effect of water vapour on the oxidation and corrosion behaviour of FeCrAl alloys that can react at high temperature forming a protective alumina scale [19] has been also examined. The protective properties of external aluminium oxides may be superior to those of $\mathrm{Cr}_{2} \mathrm{O}_{3}$ in commercial stainless steels and alloys, and this kind of materials have been proposed as candidates for heat exchangers in coal and biomass boilers, as well as in oxy-fuel environments [40], as long as creep properties are substantially improved by new production routes as in dispersion strengthened FeCrAlMo. Optimized alloys such Kanthal APTM can be used for service as a construction material in oxidising environments at temperatures as high as $1250^{\circ} \mathrm{C}$ in continuous operation [41]. Works about corrosion in the presence of steam using a $\mathrm{FeCrAl}$ alloy rich in $\mathrm{Al}$ corundum type found out that the sensitivity towards $\mathrm{Cr}$ evaporation is reduced [42, 43]. Those studies were performed in horizontal tube furnaces or inside a thermobalance device, allowing long-run experiments but involving quasi-static flow gas velocities.

This work presents a new approach to the study of the behaviour of metallic surfaces that uses high flue gas velocities, as the ones expected in convective pass in pulverized fuel burners, under oxy-steam conditions. The chromium vaporization of external oxide scales is studied as a function of metal composition at static and $20 \mathrm{~m} \cdot \mathrm{s}^{-1}$ steam-rich flue gas. The corrosion risk at high velocity steam for the selected materials is evaluated and the obtained results will provide a basis for materials selection in the future deployment of emerging technologies using high-temperature steam.

\section{Experimental}

\subsection{Materials}

Certified corrosion coupons of selected steels and alloys (SS304, SS310, I800HT, Kanthal and IN617) were purchased from Metal Samples Company. The amounts of the main elements present in the metal samples are shown in Table 1. Before the experiments, the metallic samples were cut into $10 \times 5 \mathrm{~mm}^{2}$ coupons. These bare coupons were placed in a muffle furnace at $700^{\circ} \mathrm{C}$ for 24 hours in air atmosphere to preoxidise the external surfaces and generate the characteristic oxidation scale for each composition. 


\subsection{Low-velocity corrosion tests}

Corrosion tests under steam-rich atmosphere were performed in a Netzsch STA 449 thermogravimetric analyser, equipped with a vertical down-flow vapour furnace with 30 $\mathrm{mm}$ in diameter. Steam was generated in a CEM-System ${ }^{\circledR}$ (Controlled Evaporation and Mixing) from Bronkhorst, with a precision of $0.02 \mathrm{~g} / \mathrm{h}$. Preoxidised metallic coupons were placed horizontally on top of an alumina pan and exposed to $100 \mathrm{ml} \cdot \mathrm{min}^{-1}$ of $50 \%$ steam, $45 \% \mathrm{CO}_{2}$ and $5 \% \mathrm{O}_{2}$ for 20 hours at $700^{\circ} \mathrm{C}$.

\subsection{High-speed flame treatment}

A Metco 5P-II Combustion Powder Spray Gun was used to produce high temperature and high speed combustion flames. This lightweight handheld spray gun was originally intended for occasional thermal spray needs but, for this research, it was adapted to produce high speed $\mathrm{H}_{2} \mathrm{O}$-rich flames from $\mathrm{H}_{2} / \mathrm{O}_{2}$ mixtures [44]. A Witt MM-Flex gas mixer, equipped with a proportional mixing valve with a control knob and \% scale and variable flow settings, was installed in the $\mathrm{H}_{2}$ stream to add $\mathrm{CO}_{2}$ to the system. The gun was fed with a gaseous mixture composed of $10 \mathrm{l} / \mathrm{min} \mathrm{O}_{2}, 22.5 \mathrm{l} / \mathrm{min}_{2}$ and $2.5 \mathrm{l} / \mathrm{min}$ $\mathrm{CO}_{2}\left(0.29 \mathrm{O}_{2}, 0.64 \mathrm{H}_{2}\right.$ and $0.07 \mathrm{CO}_{2}$, expressed in mole fraction) to ensure proper ignition and stability of the flame. Flame speed was indirectly calculated by in-flight alumina powder speed measured with the Accuraspray system [45], which takes into account infrared emissions of particles as dark bodies in two wavelengths. For the studied conditions and initial flame composition, nominal flame velocity was $20 \mathrm{~m} \cdot \mathrm{s}^{-1}$. Flame temperature was measured with a S-type thermocouple. Figure 1 shows the flame temperature and velocity as a function of the distance to the gun. In each experiment, the temperature of the metallic coupon was measured with a K-type thermocouple placed on the backside and located in the central line of the flame. Once the flame was started, the coupon was positioned at $0.10 \mathrm{~m}$ from the projection gun, where the metal temperature measured was $700{ }^{\circ} \mathrm{C}$. At that distance, as shown in Figure 1, flame temperature was $1600{ }^{\circ} \mathrm{C}$ which involved a calculated adiabatic composition of $70 \%$ $\mathrm{H}_{2} \mathrm{O}$ and $8 \% \mathrm{CO}_{2}$, together with the rest of unconverted comburent and other combustion products. Experiments were performed in two different configurations, as illustrated in Figure 2. Coupons perpendicular to flame line $\left(90^{\circ}\right)$ would be comparable to windside in superheater tubes, i.e. side exposed directly towards the flue gas flux. Coupons placed horizontally in the centre of flame line $\left(0^{\circ}\right)$ would represent the lateral 
side of tubes or leeside, where flux is parallel to surface. Exposure time to high-speed steam flames was 30 minutes for all experiments.

\subsection{Surface characterization}

The phase composition of the metallic surfaces was investigated by means of X-ray diffraction (XRD) analysis using a Siemens D500 diffractometer set to select $\mathrm{Cu} \mathrm{K} \alpha$ radiation. The diffraction angle $(2 \theta)$ scanned was $20-60^{\circ}$ with a step size of $0.05^{\circ}$ and a grazing incidence of $\alpha=3^{\circ}$. Surface morphology was studied by scanning electron microscopy (SEM) in a Hitachi S-3400 N microscope equipped with a $\mathrm{Si}(\mathrm{Li}) \mathrm{EDX}$ detector Röntec XFlash. Surface elemental composition was obtained with the EDX detector at x500 magnification selecting 225 x $175 \mu \mathrm{m}^{2}$ areas. Metallic coupons were mounted in epoxy resin, cut and polished in oily refrigerant, and cross sections were observed by SEM-EDX.

\section{Results and discussion}

\section{1. Preoxidation in air}

In this work, the 24 -hour preoxidation stage in air at $700^{\circ} \mathrm{C}$ was performed over each metallic sample to generate the characteristic oxide scale for each initial composition. After this pretreatment of the samples, the corrosion risk in steam-rich environment was further investigated.

SEM observation of the preoxidised surfaces confirmed the presence of the characteristic crystals of chromium oxide and spinels in the form of grains and platelets, as well as the absence of hematite needles in SS304 and SS310 (SS310 in Figure 3). The amount of the metallic elements present in the different metallic surfaces was obtained by EDX and subsequently normalized, as shown in Table 2. Preoxidised surfaces were chromium-enriched compared to the original samples, with the exception of Kanthal, whose surface was enriched in $\mathrm{Al}$, as expected. A significant increase in the manganese content was observed in SS304, SS310 and I800HT surfaces. For the same samples, the presence of $\mathrm{Ni}$ in the surface was an indication that EDX penetration range was thicker than the thickness of the formed scale and metallic substrate was also measured. 
The composition and thickness of the scales were obtained from SEM-EDX analyses of the coupons' cross sections, shown in Figure 4. A continuous thin oxide scale in the range of $2 \mu \mathrm{m}$ was formed on SS310 Preox, SS304 Preox and IN617 Preox, whereas disconnected thinner oxide spots were observed for I800HT Preox and Kanthal Preox. EDX analysis of selected points from the cross section of those scales is shown in Figure 4, where it is possible to distinguish the enrichment in manganese of the outer surfaces. The increase of Mn content in the surface was expected since other authors previously described that $\mathrm{Mn}$ in $\mathrm{Cr}$-rich $\mathrm{Ni}$-based alloys decreases the activity of chromium within the oxide, because of either the solid-solution replacement of $\mathrm{Cr}$ with $\mathrm{Mn}$ (at low levels of $\mathrm{Mn}$ ) or the formation of $\mathrm{Mn}-\mathrm{Cr}$ spinels (at high levels of $\mathrm{Mn}$ ) in external oxidised surfaces [32]. $\mathrm{MnCr}_{2} \mathrm{O}_{4}$ would be the expected spinel phase in gas with low oxygen partial pressure. Nevertheless, the $\mathrm{Mn}-\mathrm{Cr}$ spinel, stable in air, would have the stoichiometry $\mathrm{Mn}_{1+\mathrm{x}} \mathrm{Cr}_{2-\mathrm{x}} \mathrm{O}_{4}$ [46]. Mn-Cr spinels formed in SS310 Preox, identified as crystals, had a Mn-rich composition with the stoichiometry $\mathrm{Mn}_{1.65} \mathrm{Cr}_{1.35} \mathrm{O}_{4}$, like in Point 2 from Figure 4, which presents a structure close to $\mathrm{MnO}_{0.12} \mathrm{Mn}_{2} \mathrm{O}_{3} \cdot 0.46 \mathrm{Cr}_{2} \mathrm{O}_{3}$, where part of the manganese is $\mathrm{Mn}^{3+}$.

The composition of the thin scales formed during the preoxidation was studied by XRD using grazing angle method with an incidence angle of $\alpha=3^{\circ}$. The obtained results are summarized in Table 2. Stainless steels (SS304 and SS310) showed scales of iron and chromium oxides with an important presence of Mn-Cr spinel (JPCDS PDF\#71-0982), as shown in Figure 5 for SS310 Preox. A small amount of chromium oxides was detected in the I800HT and IN617 preoxidised alloys. Kanthal surface, although enriched in $\mathrm{Al}$ as confirmed by EDX analysis, did not show the characteristic alumina peaks in XRD as it could be expected due to the low temperature used during the preoxidation treatment.

\subsection{Low-velocity and high-speed tests under $80 \%$ steam}

Preoxidised coupons were treated in a steam environment at $700^{\circ} \mathrm{C}$ at two different conditions: corrosion tests in steam-rich atmosphere under quasi-static conditions for 20 hours in the steam furnace (samples named SteamF), and under high speed $\mathrm{H}_{2} \mathrm{O}$-rich combustion flames for 30 minutes.

The XRD patterns obtained for the metallic samples after treatment in the steam furnace did not exhibit any difference compared to those obtained for preoxidised coupons. 
Figure 5 shows the XRD patterns obtained for the preoxidised SS310 before and after the treatment in the steam furnace to illustrate the lack of any negligible effect caused by the steam exposure. Visual observation of SEM images of preoxidised coupons before and after treatment in the steam furnace showed minor variations in morphology as exemplified in Figure 6 for I800HT Preox, where it is possible to observe that the thin layer of platelets composed of $\mathrm{Cr}-\mathrm{Fe}$ mixed oxides remained after the treatment in the steam furnace.

Surface composition was determined by EDX and normalized values of the main elements are displayed in weight basis in Figure 7 for SS304 Preox, SS310 Preox and I800HT Preox. The 24-hour treatment in the steam furnace caused an increase of the $\mathrm{Cr}$ $+\mathrm{Mn}$ fraction in the surfaces, which indicates a progression in oxidation and the generation of a thicker oxidation scale with the subsequent decrease in the fraction of $\mathrm{Fe}$ in the substrate. In the case of Kanthal Preox and IN617 Preox (Figure 8), the treatment in the steam furnace produced an increase in the $\mathrm{Cr}+\mathrm{Al}$ surface fraction and $\mathrm{Cr}$ percentage, respectively, confirming the XRD and SEM observations where chromium reduction was not noticed.

The surface compositions of preoxidised coupons treated in steam flames for 30 minutes are also displayed in Figures 7 and 8. For all metals studied, with the exception of Kanthal, chromium presence in the surface decreased in steam-flame treated coupons compared to the preoxidised composition. Moreover, the samples exposed to steam flames with a parallel configuration to the centre line of the gun flame $\left(0^{\circ}\right)$ contained even lower Cr percentages in the surfaces, again with the exception of Kanthal Preox.

SEM images of surfaces after high-speed steam flame treatment at $0^{\circ}$ and $90^{\circ}$ for SS304 Preox, I800HT Preox and Kanthal Preox are displayed in Figure 9. The crystal structure after the flame exposition at $90^{\circ}$ was quite similar to that observed before the treatment (preoxidised samples in the first column). However, surfaces after the treatment at $0^{\circ}$ showed the destruction of the external crystalline structure in a significant extent for SS304 Preox and I800HT Preox. Kanthal Preox, as displayed in Figure 9, did not undergo significant morphological variations.

Identification of surface phases can be achieved by X-ray diffraction. Figure 10 shows the XRD patterns obtained for surfaces of SS304 Preox and SS310 Preox at $0^{\circ}$ and $90^{\circ}$. In the case of SS310 Preox, corrosion test at $0^{\circ}$ decreased the content of the mixed CrFe oxide phase and a new phase that corresponds to $\beta-\mathrm{Fe}_{2} \mathrm{O}_{3}$ (JPCDS PDF\#39-0238) 
appeared. This is an indication that the $\mathrm{Cr}_{2} \mathrm{O}_{3}$ oxide in the $\mathrm{Cr}_{2} \mathrm{O}_{3} \cdot \mathrm{Fe}_{2} \mathrm{O}_{3}$ phase is attacked by steam and oxygen, releasing volatile $\mathrm{CrO}_{2}(\mathrm{OH})_{2}$ and remaining monophasic cubic $\beta$ $\mathrm{Fe}_{2} \mathrm{O}_{3}$, with the progression of the following reaction:

$3 \mathrm{Cr}_{2} \mathrm{O}_{3} \cdot \mathrm{Fe}_{2} \mathrm{O}_{3}(\mathrm{~s})+6 \mathrm{H}_{2} \mathrm{O}(\mathrm{g})+4.5 \mathrm{O}_{2}(\mathrm{~g}) \rightarrow 6 \mathrm{CrO}_{2}(\mathrm{OH})_{2}(\mathrm{~g})+3 \beta-\mathrm{Fe}_{2} \mathrm{O}_{3}(\mathrm{~s})$

Although the formed $\beta-\mathrm{Fe}_{2} \mathrm{O}_{3}$ should transform into $\alpha-\mathrm{Fe}_{2} \mathrm{O}_{3}$ at the studied temperature, it has been reported that, depending on particle size, specific surface area and the presence of impurities, this transformation would happen at relatively high temperatures $\left(650^{\circ} \mathrm{C}\right)$ for $1 \mu \mathrm{m}$ particles [47] with a controllable and slow progression. Figure 11 shows the crystal structure in SS310 Preox after flame treatment and remaining crystals were in the range of microns. Both the size of $\beta-\mathrm{Fe}_{2} \mathrm{O}_{3}$ crystals and the short time (30 minutes) of the flame exposure made the presence of $\beta-\mathrm{Fe}_{2} \mathrm{O}_{3}$ feasible. In the case of SS304 Preox placed at $0^{\circ}$ in the steam flame, XRD showed the presence of $\alpha-\mathrm{Fe}_{2} \mathrm{O}_{3}$, which indicates that reaction (2) has proceed and the formed cubic $\mathrm{Fe}_{2} \mathrm{O}_{3}$ has evolved into $\alpha-\mathrm{Fe}_{2} \mathrm{O}_{3}$, probably due to the small size of crystals (Figure 9).

On the other hand, comparing Figure 5 with Figure 10, it is possible to see that the $(\mathrm{Mn}, \mathrm{Cr})_{3} \mathrm{O}_{4}$ spinel did not suffer any variation after the thermal treatment in the steam flame from the phase obtained in preoxidation. It has been proposed that $\mathrm{Cr}$ in the $\mathrm{Cr}_{2} \mathrm{O}_{3}$ in spinel can vaporize in the presence of steam according to reaction (3) [48]:

$2 \mathrm{MnCr}_{2} \mathrm{O}_{4}(\mathrm{~s})+3 \mathrm{H}_{2} \mathrm{O}(\mathrm{g})+2.5 \mathrm{O}_{2}(\mathrm{~g}) \rightarrow 3 \mathrm{CrO}_{2}(\mathrm{OH})_{2}(\mathrm{~g})+\mathrm{Mn}_{2} \mathrm{CrO}_{4}(\mathrm{~s})$

In the present case, the tetragonal phase $\mathrm{Mn}_{2} \mathrm{CrO}_{4}$ (JPCDS PDF\#45-0504) was not detected in the diffractogram displayed in Figure 10. This could suggest that proper preoxidation of metallic surfaces could help to reduce Cr volatilization rate [33].

Cross section images of SS304 Preox and SS310 Preox after $0^{\circ}$ and $90^{\circ}$ treatment under steam flame are shown in Figure 12. Oxidation scales seemed unaffected when treated at $90^{\circ}$ when compared to those in Figure 4 obtained after preoxidation, whereas the scale seems thinner and less adhered when treated at $0^{\circ}$. In the case of I800HT Preox, there was no variation in the XRD profile when treated at $0^{\circ}$ compared to the original preoxidised sample, but SEM images confirmed the destruction of crystalline surface structure (Figure 9) which corresponds to the depletion in surface $\mathrm{Cr}$, as shown in Figure 8. Phases of IN617 Preox seemed unaffected according to XRD and SEM observations, althoug EDX analyses (Figure 8) showed an effect of $0^{\circ}$ steam flame on the depletion of surface Cr. No effects were observed over Kanthal Preox surface using 
all the characterization techniques. Therefore, this suggests that alumina-forming steels or even alumization of external surfaces would be a suitable choice for the construction of heat exchangers in future oxy-steam boilers where high partial pressure of steam could be responsible of breakaway oxidation.

These results also advise that further studies about the risk of corrosion in steam-rich atmospheres should be performed at realistic flue gas velocities, and other factors as flame angle and metal position should be always considered. The steam flame treatment is a suitable configuration to test materials, alloying elements, coatings and surface treatments intended to protect metallic substrates. Moreover, due to the special configurarion of the projection gun, these studies could be extended to corrosionabrasion tests with realistic particle velocities and temperatures.

\section{Conclusions}

The corrosion risk of $\mathrm{Cr}$ vaporization in metallic surfaces inside oxy-steam boilers has been investigated at $700^{\circ} \mathrm{C}$ as a function of the gas velocity and the impact angle of the flue gas. The metals tested in this work (SS304, SS310, I800HT, Kanthal and IN617) were preoxidised in air before any experiment. A vapour furnace was used for quasistatic tests under $50 \% \mathrm{H}_{2} \mathrm{O}$ in $\mathrm{CO}_{2}$ and $\mathrm{O}_{2}$ for 20 hours. Studies at realistic flue gas velocity $\left(20 \mathrm{~m} \cdot \mathrm{s}^{-1}\right)$ were performed in steam flames produced with a thermal spray gun with $\mathrm{H}_{2}$ as fuel, with the metallic coupon placed both parallel and perpendicular to flame axis. The main conclusions obtained in this research were:

1. Mixed Cr-Mn and Cr-Fe external in SS304, SS310 and I800HT oxides formed during the preoxidation stage suffered chromium depletion when treated in the steam flame parallel to flame axis $\left(0^{\circ}\right)$, as a simulation of lateral flue gas pass in heat-exchanger tubing. Cr depletion was also observed in the windside of tubes $\left(90^{\circ}\right)$ but in minor extent. Cr depletion in the vapour furnace was negligible compared to high velocity treatment.

2. The vaporization of $\mathrm{Cr}$ from mixed $(\mathrm{Cr}, \mathrm{Fe})$ oxides as $\mathrm{CrO}_{2}(\mathrm{OH})_{2}$ produced $\beta-\mathrm{Fe}_{2} \mathrm{O}_{3}$ that could be transformed into $\alpha-\mathrm{Fe}_{2} \mathrm{O}_{3}$.

3. The $(\mathrm{Mn}, \mathrm{Cr})_{3} \mathrm{O}_{4}$ spinel formed on stainless steels did not suffer $\mathrm{Cr}$ depletion, but its presence did not provide any protection against $\mathrm{Cr}$ volatilization in preoxidised SS310 and SS304 after the steam flame treatment. 
4. Elemental surface analysis indicated depletion in the external chromium in preoxidised alloys I800HT and IN617 with the high-speed steam flame treatment.

According to the presented results, strengthened alumina-forming steels and aluminized austenitic steels should be considered as suitable materials for the construction of heat exchange surfaces in processes with high steam partial pressures at high temperature.

\section{Acknowledgements}

This work was funded by the Spanish Ministry of Economy, Industry and Competitiveness under contract ENE2015-67448-C2-2-R. 


\section{References}

[1] International Energy Agency. Technology Roadmap: Carbon capture and storage. In:

https://www.iea.org/publications/freepublications/publication/TechnologyRoad mapCarbonCaptureandStorage.pdf, ed. Paris, France; 2013:63.

[2] Chen L, Yong SZ, Ghoniem AF. Oxy-fuel combustion of pulverized coal: Characterization, fundamentals, stabilization and CFD modeling. Progress in Energy and Combustion Science 2012;38(2):156-214.

[3] Stanger R, Wall T, Spörl R, Paneru M, Grathwohl S, Weidmann M, et al. Oxyfuel combustion for $\mathrm{CO}_{2}$ capture in power plants. International Journal of Greenhouse Gas Control 2015;40:55-125.

[4] Lockwood T. Development in oxyfuel combustion of coal. In: CCC/240, ed. London: IEA Clean Coal Centre; 2014:122.

[5] Hagi H, Nemer M, Le Moullec Y, Bouallou C. Towards Second Generation Oxy-pulverized Coal Power Plants: Energy Penalty Reduction Potential of Pressurized Oxy-combustion Systems. Energy Procedia 2014;63:431-9.

[6] Seepana S, Jayanti S. Steam-moderated oxy-fuel combustion. Energy Conversion and Management 2010;51(10):1981-8.

[7] Zanganeh K, Salvador C, Mitrovic M, Shafeen A. $3^{\text {rd }}$ generation oxy-fuel combustion systems. $3^{\text {rd }}$ IEAGHG International Oxy-Combustion Workshop. Yokohama, Japan; 2008.

[8] Salvador C, Mitrovic M, Zanganeh K. Novel oxy-steam burner for zeroemission power plants. $1^{\text {st }}$ Oxyfuel Combustion Conference. Cottbus, Germany; 2009.

[9] Sheng L, Liu X, Si J, Xu Y, Zhou Z, Xu M. Simulation and comparative exergy analyses of oxy-steam combustion and $\mathrm{O}_{2} / \mathrm{CO}_{2}$ recycled combustion pulverizedcoal-fired power plants. International Journal of Greenhouse Gas Control 2014;27:267-78.

[10] Tu Y, Liu H, Su K, Chen S, Liu Z, Zheng C, et al. Numerical study of $\mathrm{H}_{2} \mathrm{O}$ addition effects on pulverized coal oxy-MILD combustion. Fuel Processing Technology 2015;138:252-62. 
[11] Jin B, Zhao H, Zou C, Zheng C. Comprehensive investigation of process characteristics for oxy-steam combustion power plants. Energy Conversion and Management 2015;99:92-101.

[12] Lei K, Ye B, Cao J, Zhang R, Liu D. Combustion Characteristics of Single Particles from Bituminous Coal and Pine Sawdust in $\mathrm{O}_{2} / \mathrm{N}_{2}, \mathrm{O}_{2} / \mathrm{CO}_{2}$, and $\mathrm{O}_{2} / \mathrm{H}_{2} \mathrm{O}$ Atmospheres. Energies 2017;10(11):1695.

[13] Cai L, Zou C. Oxy-steam Combustion. In: Zeng Chuguang LZ, editor Oxy-Fuel Combustion Fundamentals, Theory and Practive. United Kingdom: Elsevier; 2018, p. 325-38.

[14] Dueso C, Mayoral MC, Andrés JM, Escudero AI, Díez LI. Towards oxy-steam combustion: the effect of increasing the steam concentration on coal reactivity. Fuel;239:534-46.

[15] Cairns PEC, Clements BR, Hughes R, Herage T, Zheng L, Macchi A, et al. High-Pressure Oxy-Firing (HiPrOx) of Fuels with Water for the Purpose of Direct Contact Steam Generation. Energy \& Fuels 2015;29(7):4522-33.

[16] Anderson R, Hustad C, Skutley P, Hollis R. Oxy-fuel Turbo Machinery Development for Energy Intensive Industrial Applications. Energy Procedia 2014;63:511-23.

[17] Pronske K. Oxy-fuel technology for energy production. COSIA Innovation Summit. Banff, Canadá; 2015.

[18] Saunders SRJ, Monteiro M, Rizzo F. The oxidation behaviour of metals and alloys at high temperatures in atmospheres containing water vapour: A review. Progress in Materials Science 2008;53(5):775-837.

[19] Nguyen TD, Peng X, Zhang J, Young DJ. Corrosion resistance of chromised and aluminised coatings in wet $\mathrm{CO}_{2}$ gas at $650^{\circ} \mathrm{C}$. Surface and Coatings Technology 2017;316:226-38.

[20] Nguyen TD, La Fontaine A, Cairney JM, Zhang J, Young DJ. Effects of Si, Mn, and water vapour on the microstructure of protective scales grown on $\mathrm{Fe}-20 \mathrm{Cr}$ in $\mathrm{CO}_{2}$ gas. Materials at High Temperatures 2018;35(1-3):22-9.

[21] Xie Y, Nguyen TD, Zhang J, Young DJ. Corrosion behaviour of Ni-Cr alloys in wet $\mathrm{CO}_{2}$ atmosphere at 700 and $800{ }^{\circ} \mathrm{C}$. Corrosion Science 2019;146:28-43. 
[22] Mu N, Jung KY, Yanar NM, Meier GH, Pettit FS, Holcomb GR. Water Vapor Effects on the Oxidation Behavior of $\mathrm{Fe}-\mathrm{Cr}$ and $\mathrm{Ni}-\mathrm{Cr}$ Alloys in Atmospheres Relevant to Oxy-fuel Combustion. Oxidation of Metals 2012;78(3):221-37.

[23] Huenert D, Kranzmann A. Impact of oxyfuel atmospheres $\mathrm{H}_{2} \mathrm{O} / \mathrm{CO}_{2} / \mathrm{O}_{2}$ and $\mathrm{H}_{2} \mathrm{O} / \mathrm{CO}_{2}$ on the oxidation of ferritic-martensitic and austenitic steels. Corrosion Science 2011;53(6):2306-17.

[24] Huczkowski P, Najima S, Chyrkin A, Grüner D, Quadakkers WJ. Corrosion behavior of candidate heat exchanger materials in oxidizing and reducing gases relevant to oxyfuel power plants. Materials at High Temperatures 2018;35(13):275-90.

[25] Intiso L, Johansson L-G, Canovic S, Bellini S, Svensson J-E, Halvarsson M. Oxidation Behaviour of Sanicro $25(42 \mathrm{Fe} 22 \mathrm{Cr} 25 \mathrm{NiWCuNbN})$ in $\mathrm{O}_{2} / \mathrm{H}_{2} \mathrm{O}$ Mixture at $600{ }^{\circ} \mathrm{C}$. Oxidation of Metals 2012;77(5):209-35.

[26] Intiso L, Johansson L-G, Svensson J-E, Halvarsson M. Oxidation of Sanicro 25 $(42 \mathrm{Fe} 22 \mathrm{Cr} 25 \mathrm{NiWCuNbN})$ in $\mathrm{O}_{2}$ and $\mathrm{O}_{2}+\mathrm{H}_{2} \mathrm{O}$ Environments at $600-750{ }^{\circ} \mathrm{C}$. Oxidation of Metals 2015;83(3):367-91.

[27] Opila EJ, Myers DL, Jacobson NS, Nielsen IMB, Johnson DF, Olminsky JK, et al. Theoretical and Experimental Investigation of the Thermochemistry of $\mathrm{CrO}_{2}(\mathrm{OH})_{2}(\mathrm{~g})$. The Journal of Physical Chemistry A 2007;111(10):1971-80.

[28] Young DJ, Pint BA. Chromium Volatilization Rates from $\mathrm{Cr}_{2} \mathrm{O}_{3}$ Scales into Flowing Gases Containing Water Vapor. Oxidation of Metals 2006;66(3):13753.

[29] Dudziak T, Hussain T, Simms NJ, Syed AU, Oakey JE. Fireside corrosion degradation of ferritic alloys at $600^{\circ} \mathrm{C}$ in oxy-fired conditions. Corrosion Science 2014;79:184-91.

[30] Asteman H, Segerdahl K, Svensson JE, Johansson LG. The Influence of Water Vapor on the Corrosion of Chromia-Forming Steels. Materials Science Forum 2001;369-372:277-86.

[31] Yang Z, Xia G, Singh P, Stevenson JW. Effects of water vapor on oxidation behavior of ferritic stainless steels under solid oxide fuel cell interconnect exposure conditions. Solid State Ionics 2005;176(17):1495-503. 
[32] Sachitanand R, Sattari M, Svensson J-E, Froitzheim J. Evaluation of the oxidation and $\mathrm{Cr}$ evaporation properties of selected $\mathrm{FeCr}$ alloys used as $\mathrm{SOFC}$ interconnects. International Journal of Hydrogen Energy 2013;38(35):15328-34.

[33] Wongpromrat W, Berthomé G, Parry V, Chandra-ambhorn S, Chandra-ambhorn W, Pascal C, et al. Reduction of chromium volatilisation from stainless steel interconnector of solid oxide electrochemical devices by controlled preoxidation. Corrosion Science 2016;106:172-8.

[34] Huczkowski P, Lehnert W, Angermann HH, Chyrkin A, Pillai R, Grüner D, et al. Effect of gas flow rate on oxidation behaviour of alloy 625 in wet air in the temperature range $900-1000{ }^{\circ} \mathrm{C}$. Materials and Corrosion 2016;68(2):159-70.

[35] Robinson AL, Buckley SG, Baxter LL. Experimental Measurements of the Thermal Conductivity of Ash Deposits: Part 1. Measurement Technique. Energy \& Fuels 2001;15(1):66-74.

[36] Becker A, Schiemann M, Scherer V, Haxter D, Mayer J. Pulverized coal ignition testing under air-fired conditions using the Zelkowski method: comparison of coals of different rank and provenience. Energy Procedia 2017;120:173-80.

[37] Tylczak JH, Holcomb GR. Measurement of Cr Evaporation at $760{ }^{\circ} \mathrm{C}$ for Several Nickel Based Alloys at Moderate Velocities. ECS Transactions 2017;75(28):43-55.

[38] Holcomb GR, Alman DE. The effect of manganese additions on the reactive evaporation of chromium in Ni-Cr alloys. Scripta Materialia 2006;54(10):18215.

[39] Sachitanand R, Svensson J-E, Froitzheim J. The Influence of Cr Evaporation on Long Term Cr Depletion Rates in Ferritic Stainless Steels. Oxidation of Metals 2015;84(3):241-57.

[40] Montgomery M, Bjurman M, Hjørnhede A, Rombrecht HB, Lisk A, Krautz HJ. High temperature corrosion investigation in an oxyfuel combustion test rig. Materials and Corrosion 2015;66(3):257-69.

[41] Jönsson B, Lu Q, Chandrasekaran D, Berglund R, Rave F. Oxidation and Creep Limited Lifetime of Kanthal APMT®, a Dispersion Strengthened FeCrAlMo 
Alloy Designed for Strength and Oxidation Resistance at High Temperatures. Oxidation of Metals 2013;79(1):29-39.

[42] Eklund J, Jönsson B, Persdotter A, Liske J, Svensson JE, Jonsson T. The influence of silicon on the corrosion properties of FeCrAl model alloys in oxidizing environments at $600^{\circ} \mathrm{C}$. Corrosion Science 2018;144:266-76.

[43] Hellström K, Israelsson N, Halvarsson M, Canovic S, Svensson J-E, Johansson L-G. The Oxide Scales Formed on a Dispersion-Strengthened Powder Metallurgical FeCrAl Alloy at $900{ }^{\circ} \mathrm{C}$ in $\mathrm{O}_{2}$ and in $\mathrm{O}_{2}+\mathrm{H}_{2} \mathrm{O}$. Oxidation of Metals 2015;84(1):1-19.

[44] Mayoral MC, Andrés JM, Izquierdo MT, Rubio B. Pyrrhotite deposition through thermal projection to simulate iron sulphide slagging in oxyfuel combustion. Fuel 2012;101:197-204.

[45] Bisson JF, Lamontagne M, Moreau C, Pouliot L, Blain J, Nadeau F. Ensemble in-flight particle diagnostics under thermal spray conditions. In: Berndt CC, Khor KA, Lugscheider EF, eds. International Thermal Spray Conference. Thermal Spray 2001: New surfaces for a new millenium. Singapore: ASM International; 2001:705-14.

[46] Naoumidis A, Schulze HA, Jungen W, Lersch P. Phase studies in the chromiummanganese-titanium oxide system at different oxygen partial pressures. Journal of the European Ceramic Society 1991;7(1):55-63.

[47] Danno T, Nakatsuka D, Kusano Y, Asaoka H, Nakanishi M, Fujii T, et al. Crystal Structure of $\beta-\mathrm{Fe}_{2} \mathrm{O}_{3}$ and Topotactic Phase Transformation to $\alpha-\mathrm{Fe}_{2} \mathrm{O}_{3}$. Crystal Growth \& Design 2013;13(2):770-4.

[48] Pettersson C, Jonsson T, Proff C, Halvarsson M, Svensson J-E, Johansson L-G. High Temperature Oxidation of the Austenitic (35Fe27Cr31Ni) Alloy Sanicro 28 in $\mathrm{O}_{2}+\mathrm{H}_{2} \mathrm{O}$ Environment. Oxidation of Metals 2010;74(1):93-111. 
Table 1. Composition of the metallic materials.

\begin{tabular}{lccccccccc}
\hline \multicolumn{1}{c}{ wt.\% } & Fe & Cr & Ni & Mo & Co & Mn & Ti & Al & Si \\
\hline SS304 & 71.70 & 18.16 & 8.16 & 0.05 & & 1.31 & & & 0.48 \\
SS310 & 52.00 & 25.00 & 21.00 & & & 2.00 & & & 1.50 \\
I800HT & 45.69 & 19.88 & 31.30 & & & 0.87 & 0.57 & 0.46 & 0.36 \\
Kanthal & 72.90 & 21.10 & & & & 0.13 & & 5.70 & 0.17 \\
IN617 & 1.03 & 21.93 & 54.70 & 8.84 & 11.70 & 0.18 & 0.49 & 0.96 & 0.12 \\
\hline
\end{tabular}


Table 2. Surface EDX analysis and XRD peak assignation of the metallic samples after preoxidation.

\begin{tabular}{|c|c|c|c|c|c|c|c|c|c|c|c|c|c|}
\hline \multirow[b]{2}{*}{ Sample } & \multicolumn{9}{|c|}{ Surface EDX } & \multicolumn{4}{|c|}{ Grazing angle XRD } \\
\hline & Al & $\mathbf{S i}$ & $\mathbf{T i}$ & Co & $\mathrm{Cr}$ & Mn & $\mathbf{F e}$ & $\mathbf{N i}$ & Mo & $\begin{array}{c}\text { Hematite } \\
\mathrm{Fe}_{2} \mathrm{O}_{3} \\
\end{array}$ & $\begin{array}{c}\text { Mixed oxide } \\
3 \mathrm{Cr}_{2} \mathrm{O}_{3} \cdot \mathrm{Fe}_{2} \mathrm{O}_{3} \\
\end{array}$ & $\begin{array}{c}\text { Spinel } \\
(\mathrm{Cr}-\mathrm{Mn}) \mathrm{O}_{4} \\
\end{array}$ & $\begin{array}{c}\text { Eskolaite } \\
\mathrm{Cr}_{2} \mathrm{O}_{3} \\
\end{array}$ \\
\hline SS304 Preox & & 4.49 & & & 40.50 & 7.19 & 43.91 & 3.90 & & $\sqrt{ }(12 \%)$ & $\sqrt{ } \sqrt{ }(73 \%)$ & $\sqrt{ }(15 \%)$ & - \\
\hline SS310 Preox & & 2.71 & & & 58.21 & 21.79 & 12.66 & 4.02 & & - & $\sqrt{ } \sqrt{ }(70 \%)$ & $\sqrt{ } \sqrt{ }(30 \%)$ & \\
\hline I800HT Preox & 0.89 & 2.59 & 1.56 & & 42.71 & 5.12 & 29.66 & 17.47 & & - & $\sqrt{ }$ & - & - \\
\hline Kanthal Preox & 12.02 & 1.33 & & & 22.13 & & 64.52 & & & - & - & - & - \\
\hline IN617 Preox & 1.21 & 2.04 & & 10.18 & 45.24 & & 1.28 & 34.04 & 5.80 & - & - & - & $\sqrt{ }$ \\
\hline
\end{tabular}




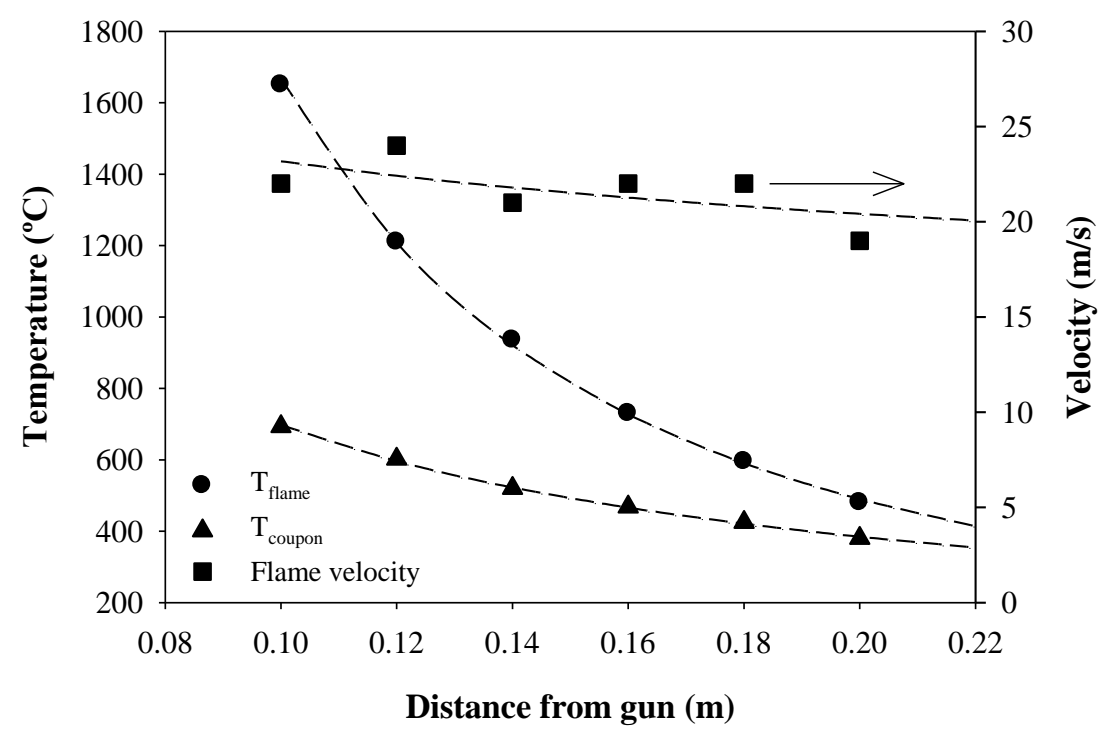

Figure 1. Temperature at flame centre line, temperature at coupon surface and flame velocity as a function of distance from gas nozzle. 


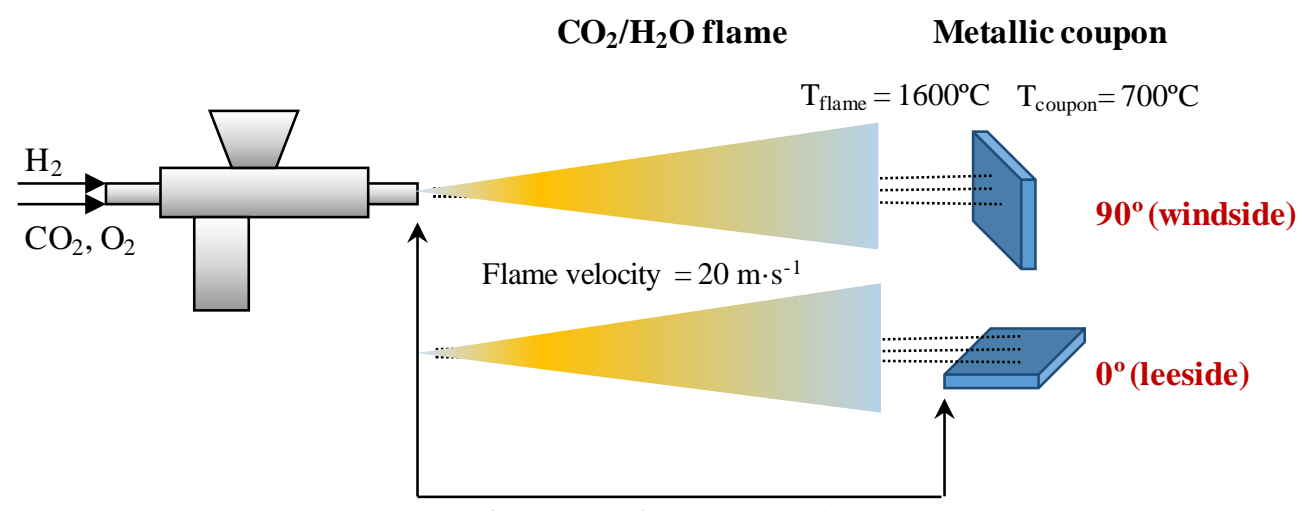

Distance nozzle - coupon $=0.10 \mathrm{~m}$

Figure 2.Scheme of the projection gun, steam flame and coupon configurations. 


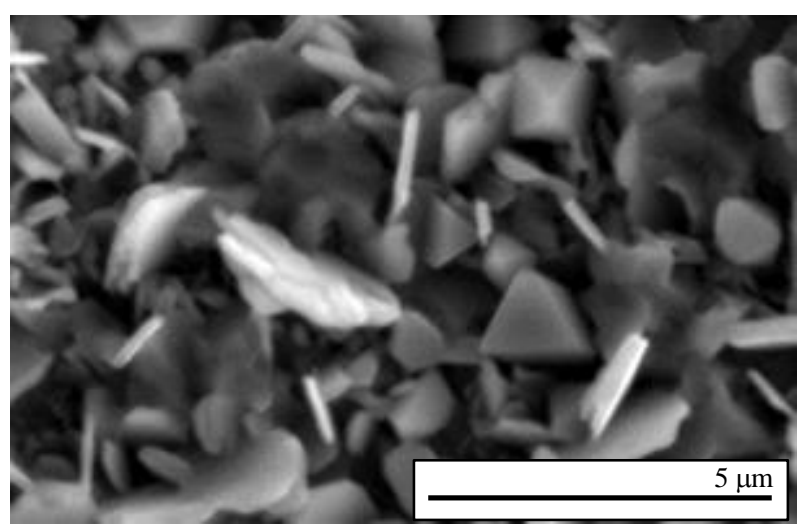

Figure 3. SEM image of preoxidised SS310. 


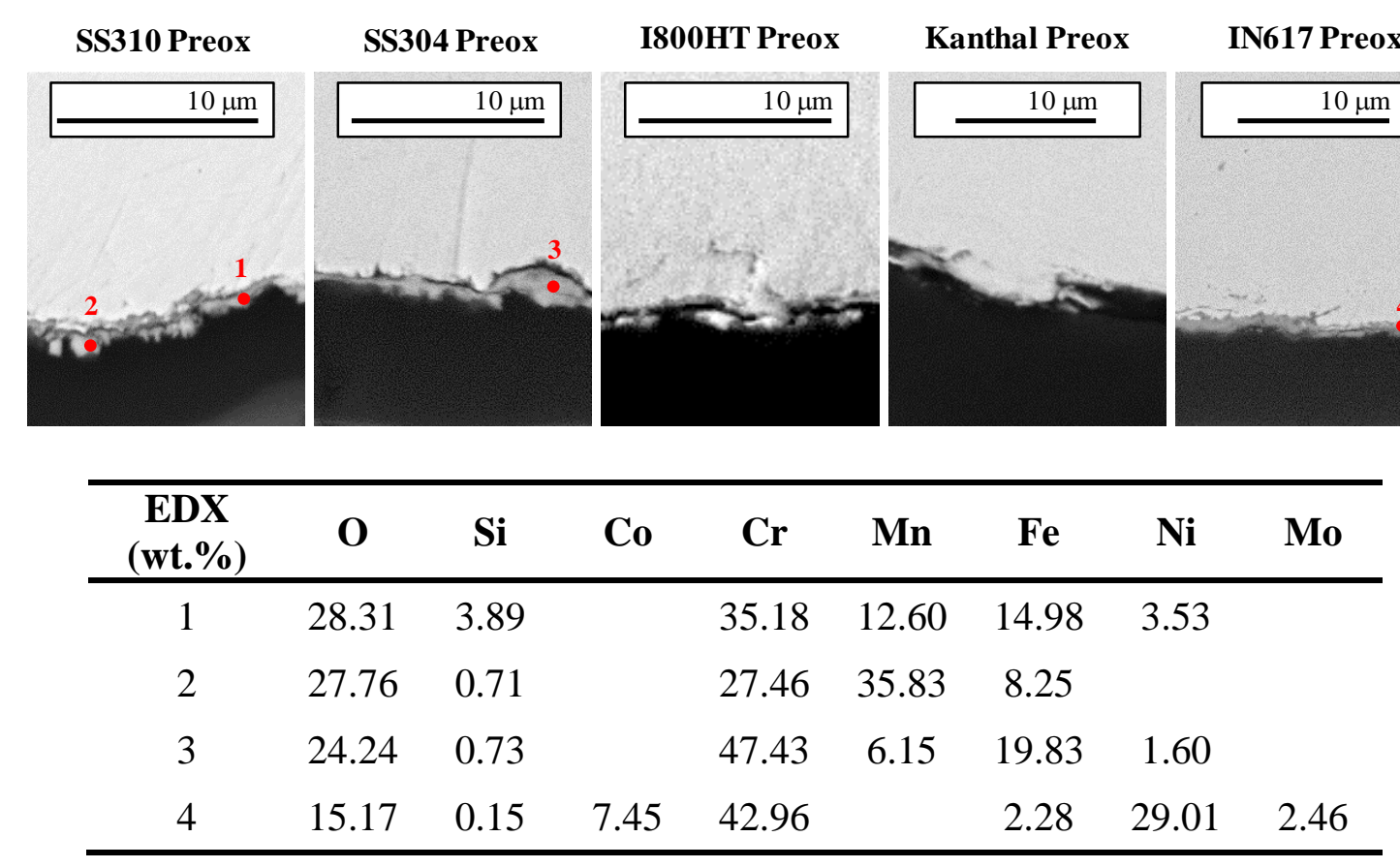

Figure 4. Backscattered image of cross sections of preoxidised metallic coupons and EDX composition in wt.\% of selected points. 


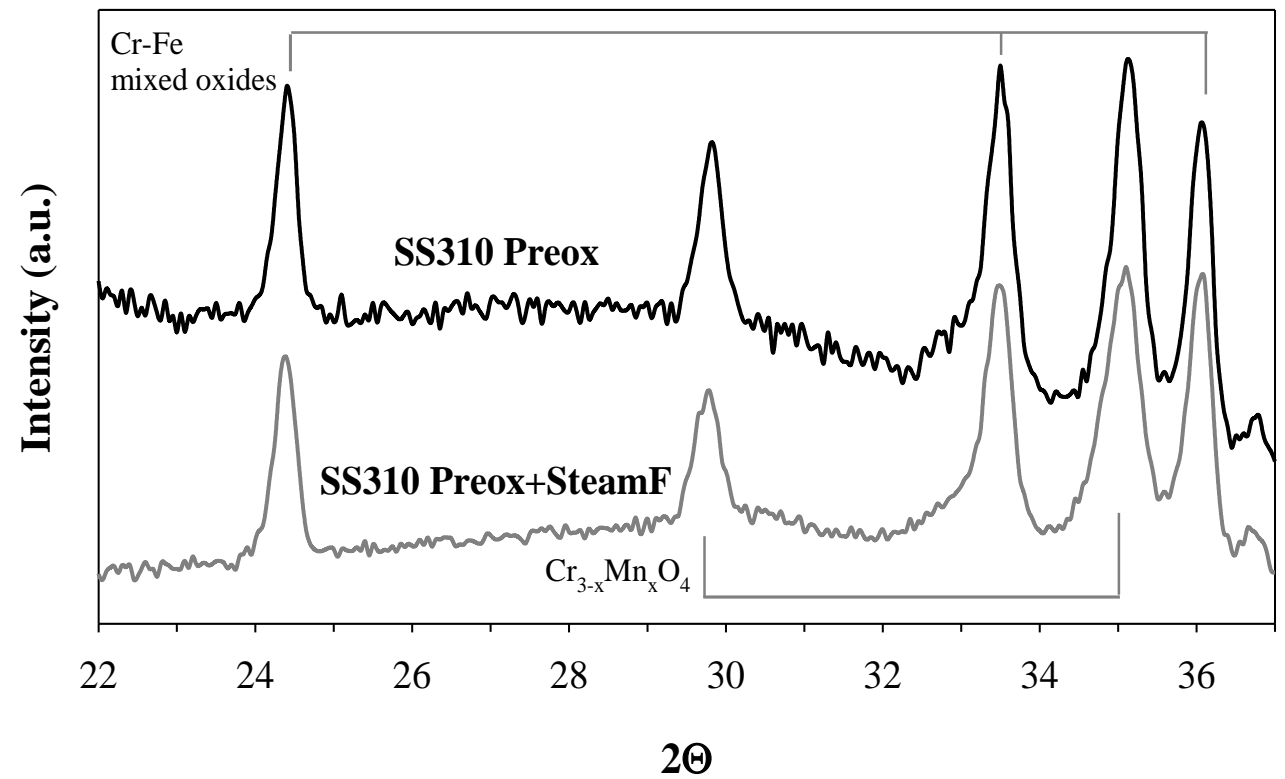

Figure 5. XRD of preoxidised SS310 before and after treatment in steam furnace at $700^{\circ} \mathrm{C}$ for 24 hours. 



Figure 6. SEM images of preoxidised I800HT before and after treatment in the steam furnace at $700^{\circ} \mathrm{C}$ for 24 hours. 


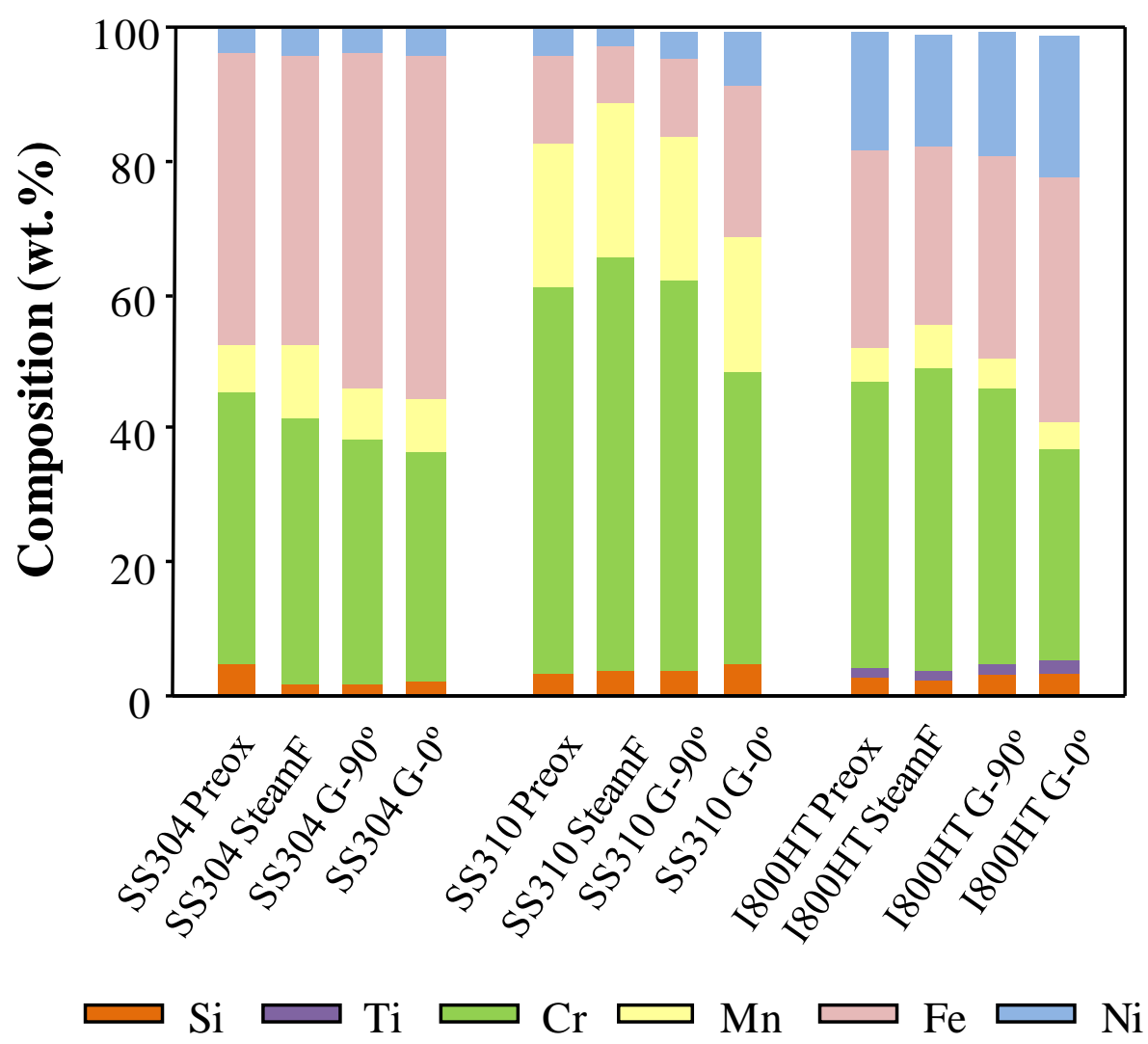

Figure 7. EDX composition of SS304, SS310 and I800HT surfaces, normalized to main elements. 


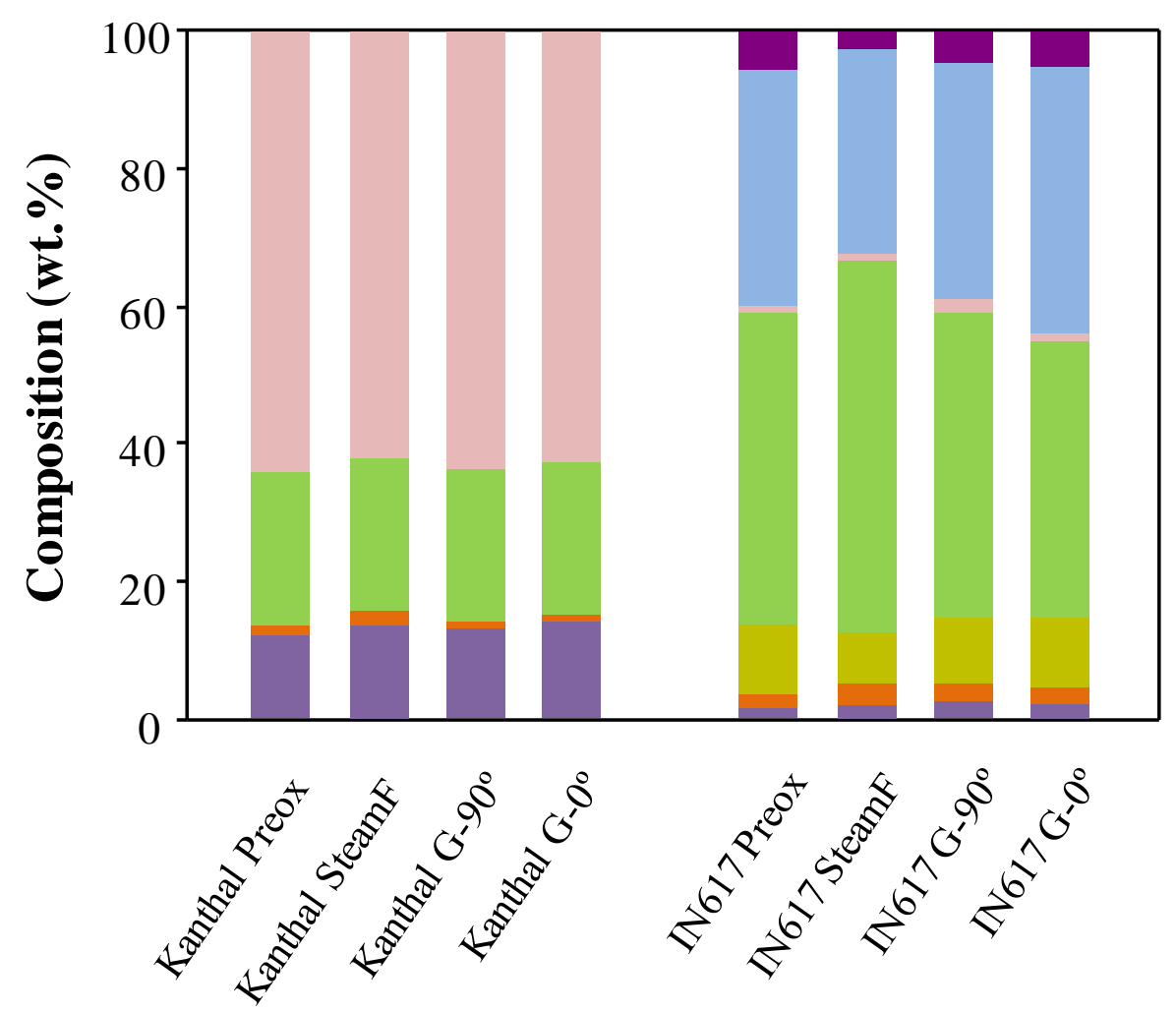

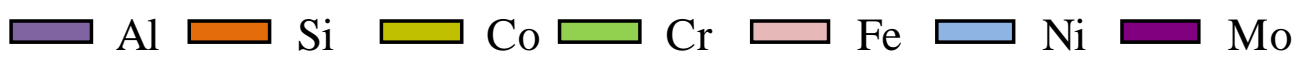

Figure 8. EDX composition of Kanthal and IN617 surfaces, normalized to main elements. 


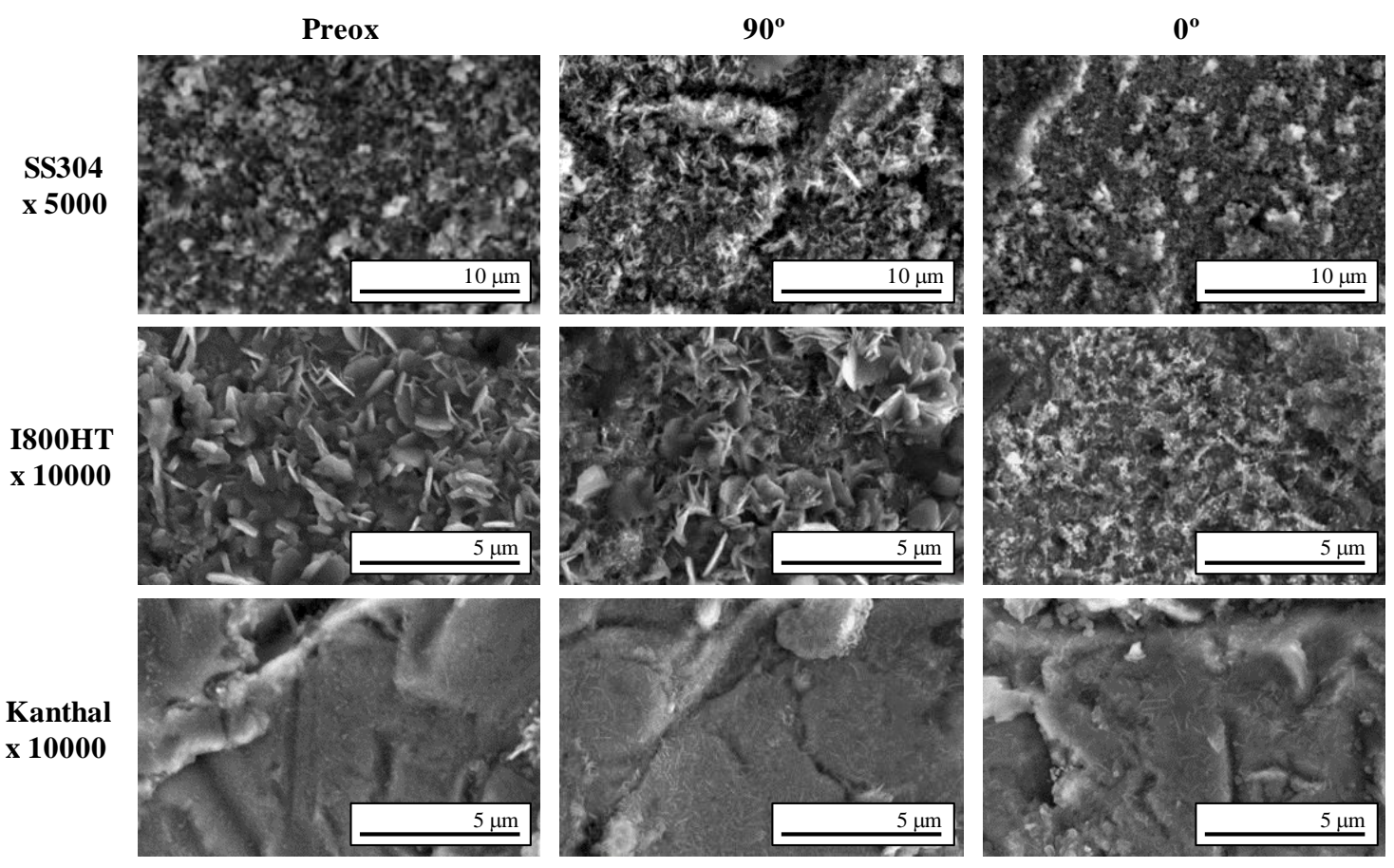

Figure 9. SEM images of preoxidised SS304, I800HT and Kanthal before and after treatment in steam flame at $0^{\circ}$ and $90^{\circ}$. 




Figure 10. XRD of preoxidised SS304 and SS310 after treatment in steam flame at $0^{\circ}$ and $90^{\circ}$. 


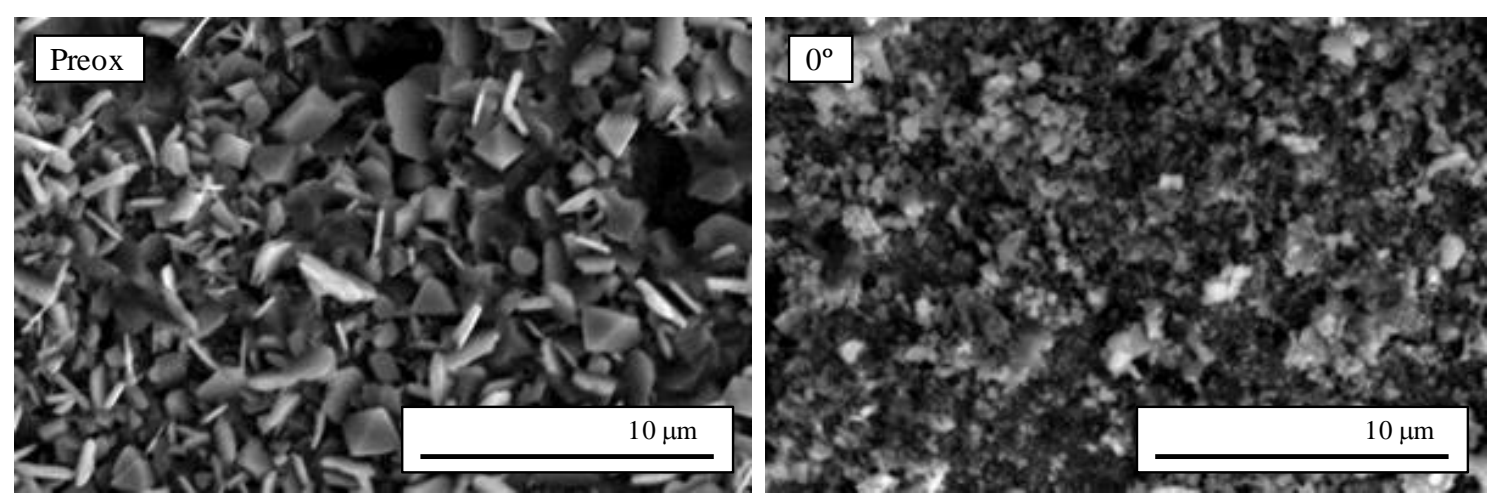

Figure 11. SEM images of preoxidised SS310 before and after treatment in steam flame at $0^{\circ}$. 


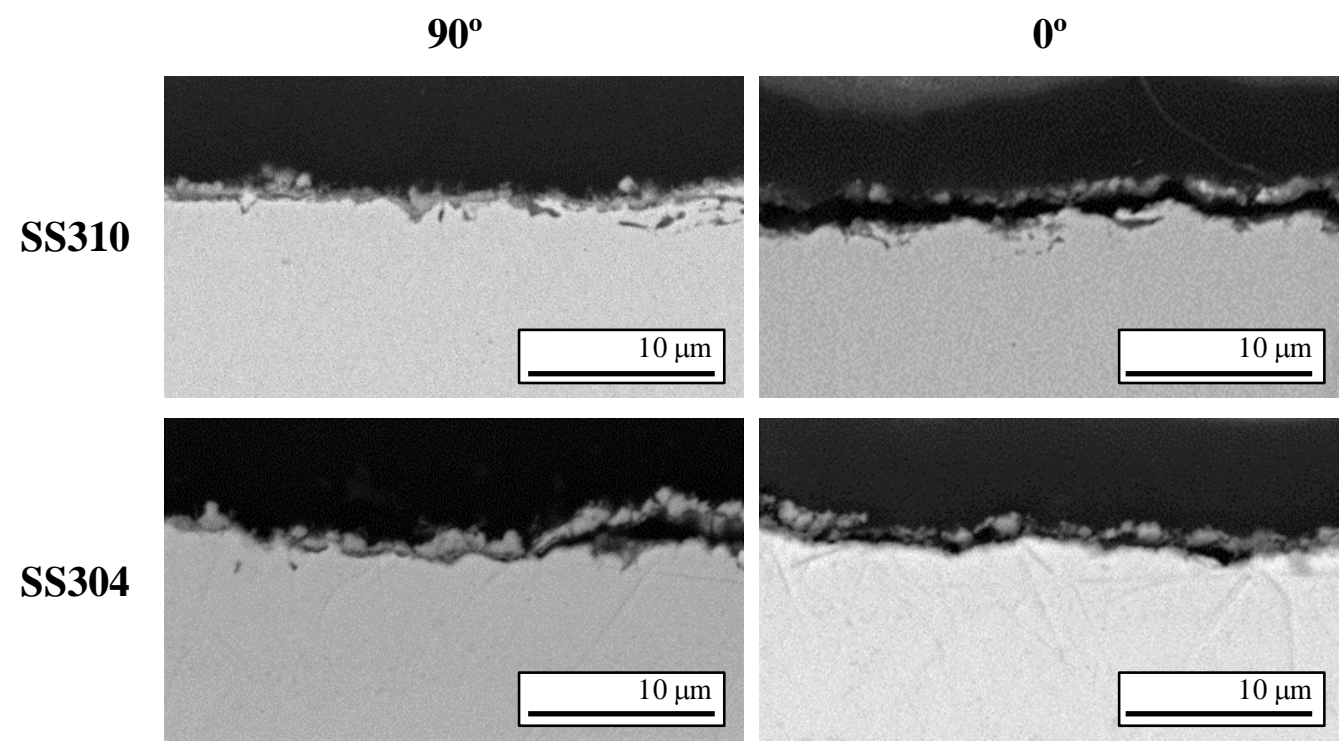

Figure 12. Backscattered image of cross sections of preoxidised SS310 and SS304 coupons after treatment in steam flame at $0^{\circ}$ and $90^{\circ}$. 